\title{
ZAB RIVER (IRAQ) SINUOSITY AND MEANDERING ANALYSIS BASED ON THE REMOTE SENSING DATA
}

\author{
B. Kalantar ${ }^{1, *}$, M. H. Ameen ${ }^{2}$, H. J. Jumaah ${ }^{3}$, S. J. Jumaah ${ }^{4}$, A. A. Halin ${ }^{5}$ \\ ${ }^{1}$ RIKEN Center for Advanced Intelligence Project, Goal-Oriented Technology Research Group, Disaster Resilience Science Team, \\ Tokyo 103-0027, Japan - bahareh.kalantar@ riken.jp \\ ${ }^{2}$ Dept. of Environmental Engineering, Engineering College, Tikrit University, Tikrit, Iraq - Mohammed.hashim@tu.edu.iq \\ ${ }^{3}$ Dept. of Environment and Pollution Engineering, Technical College of Kirkuk, Northern Technical University, Kirkuk 36001, Iraq \\ - huda80@ntu.edu.iq \\ ${ }^{4}$ Dept. of Physics, College of Education for Pure Sciences, University of Kirkuk, Kirkuk 36001, Iraq - sarah.physic2019@ gmail.com \\ ${ }^{5}$ Dept. of Multimedia, Faculty of Computer Science and Information Technology, Universiti Putra Malaysia, Serdang, 43400 \\ Selangor, Malaysia - alfian@ieee.org
}

Commission III, WG III/1

KEY WORDS: Zab River, Sinuosity Index, Meandering, Remote sensing, GIS, Landsat images.

\begin{abstract}
:
This work studies the meandering and change of paths along the Zab River in Iraq. Landsat-5 TM, Landsat-7 ETM+ and Landsat-8 (2sets) images were acquired from the years 1989, 1999, 2015 and 2019, respectively, which were used together with Remote sensing and Geographic Information Systems (GIS) techniques to study the changes. To determine the river/stream shape, the Sinuosity Index was calculated to classify Zab River segments into either the straight, sinuous or meandering class. Our findings via image analysis show coarse river migration and that most river segments fall into the two classes of sinuous and meander. In addition, it seems that the east bank of the Zab River region of the basin has extremely shifted where the river passes near the Kirkuk governorate.
\end{abstract}

\section{INTRODUCTION}

Meanders are a geomorphic phenomenon of change that occurs when rivers age. It causes progressive course relocation of rivers and stream as well as riverbank erosion (Ahmed and Fawzi 2011). Meanders are characterized by repetitious patterns of bends/curves (mostly sinusoidal) that in certain cases form exaggerated round circles (Suryavanshi et al. 2011). Many geological researches are interested to investigate meandering rivers due to the surrounding dynamic and natural processes of river platform shifting, avulsion and weathering from which deposition and sedimentation can form (Hecher et al. 2013). Understanding all these phenomena can help identify problems such as flooding and water quality issues (Kamarudin et al. 2015). This in turn will be instrumental in guiding mitigation as well as any necessary safety policies.

The Sinuosity Index (SI) is one measurement used to understand shape distortions of rivers/streams, where it evaluates the effect of a river's paths over a particular region (and vice versa) (Kumar et al. 2014). Rivers in the world meander because of natural phenomena such floods and load flow of channel slope. It can even happen due to human activities such as building of dams, agricultural project or even settlements building (Kumar et al., 2016).

Generally, the channel design or river map view is relatively viewed as a straight, meander, or braided (Leopold and Wolman., 1957; Brice., 1964; Parker., 1976; Thompson., 1986; Ahmed and Fawzi., 2011; Kumar et al., 2016). Meander and sinuous are synonymous and indicate the same meaning of the repetitious shape of the river bends (Suryavanshi et al. 2011).

\footnotetext{
* Corresponding author
}

Lengthy rivers rarely follow a straight channel path as most of its streams tend to meandering, especially when not confined to a narrow valley or gully. The channel curve adds extra flow energy dissipating that is not present in the straight pattern, the energy loss is a result of an alteration of the flow path (Das., 2012).

Lateral migration rate of rivers widely vary with values reaching 800-meter per year (Shields et al. 2000). The study of river meandering is prime importance in researchers' consideration and fluvial scientists (Kumar et al., 2016). The different scales and characteristics of shear failure are assumed as the primary reason for riverbank erosion (Kotoky et al., 2005). Riverbanks alluvium excavations are additionally remarkably responsible in river erosion and shifting in the path, which is one of the reasons for the change in the sinuosity index of the course (Sapkale et al., 2016).

Classifications of meandering patterns have been proposed in the work of Callander (1978) and Surian (1999). These include classifications for single bends and also for patterns such as regular meandering, irregular and twisting. Hooke (1984) also suggested the sinuous braided classification. In this work, we use the Sinuosity Index, which is can be used to determine whether a river/stream is sinusoidal or meandering based on predetermined values. The SI has already been successfully used in works such as Mueller (1968); and Kusratmoko et al. (2019).

Remotely sense digital data coupled with advanced information extraction technologies can be used to obtain the necessary measurements. These measurements allow channel shifting of the river to be identified, whose analysis results help in implementing multi-purpose planning and other relevant applications (Aher et al., 2012). Some articles have mentioned methods to monitor spatio-temporal changes such as lateral river 
stream migration (Hecher et al. 2013). Maps can be generated based on these data, mainly using remote sensing and GIS technologies, which can help in planning and decision-making tasks (Mojaddadi et al. 2017). In the field of remote sensing, ArcGIS is a software package with tools for inclusive rasterbased spatial analysis (Jumaah et al. 2018). It allows effective information processing and investigating to help in interpreting and visualizing data properly and introduce beneficial outputs (Jumaah et al. 2019). Remote sensing images and GIS technologies confer high potentiality to analyses the shifting of the river morphology (Kumar et al. 2018).

In this study, we calculate the Sinuosity Index of segments from the Zab River in Iraq. We rely on remotely sensed imagery data, which are obtained from satellite imagery sources. This study reviews river channel path behavior to recognize changes that happen in the ambient environment. This is so that we could study and examine the problems that affect land uses. Two types of river path form identified meandering and sinuous. The paths on areas that subjected to shift also have been reviewed.

\section{STUDY AREA}

The study area chosen is the Zab River, which is $65 \mathrm{~km}$ long and

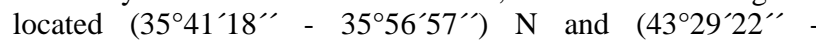
$\left.44^{\circ} 57^{\prime} 16^{\prime \prime}\right)$ E, (Figure 1). It is one of the five tributaries of the Tigris River and situated northeastern of Iraq and northwestern of Iran (Al-Saady et al. 2016). The river also flows through the Sulaymaniyah, Arbil and Kirkuk governorates before emptying at the Tigris. The lower Zab River is the primary source of drinking water for the Kirkuk communities as well as being indispensable for the farming industry.

The northern and northeastern parts of the region have semi-arid climate whereas the southern and southwestern parts' climate are arid. Average rainfall in the highlands for the northern and northeastern regions reaches $850 \mathrm{~mm}$ per annum. In contrast, annual rainfall significantly decreases to $315 \mathrm{~mm}$ in the lower parts of the southern and southwestern region.

In the recent decade, areas surrounding the Zab River basin have experienced rapid urbanization leading to increased land use, population growth and environmental changes. Among tasks that were starting to look critical are water supply management and water quality monitoring (Al-Saady et al., 2015). Around this time also, the northern part of Iraq was influenced by drastic climatic variations such as long and dry seasons as well as water shortages. The latter was also instrumental for the lack of seasonal flooding in the region. However, irregular flooding occurred nonetheless during winter due to massive rainfall, with no dams and industrial drainage to manage the excess water volume. According to Saeedrashed and Guven (2013), all the aforementioned issues caused massive social and economic problems in the effected areas. It is believed that being able to analyze how the river paths change and also how riverbanks reshape, would give insight on how such changes affect surrounding land use and water quality. Such information allows the most suitable and timely policies to be planned out.

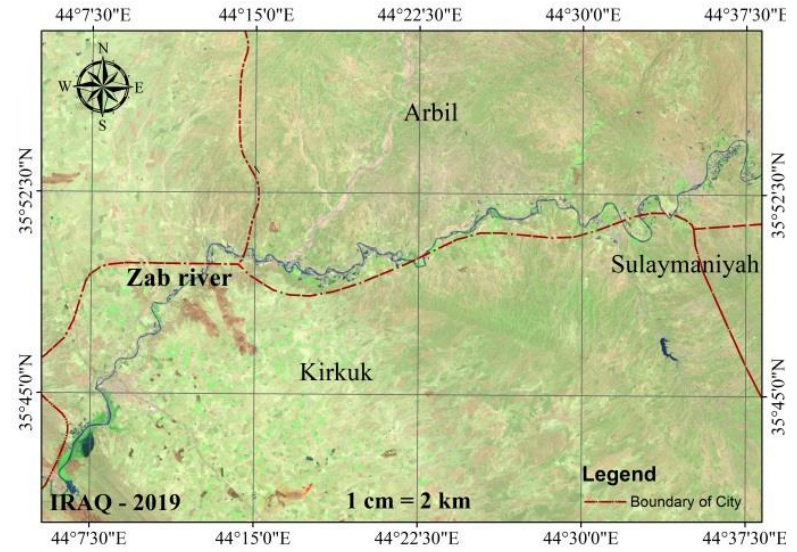

Figure 1. The path of the Zab River within the study area.

\section{METHODOLOGY}

Measurements related the Zab River's spatial and temporal channel shifts were performed using remote sensing and GIS technologies. In this study, we performed on-site observations as well as calculated the Sinuosity Index (SI) in order to detect and identify the meandering of the river.

Four sets of images were used in this study: one set of Landsat-5 TM images, one set of Landsat-7 ETM+ images, and two set of Landsat-8 images. All images were taken from the years 1989, 1999, 2015 and 2019, respectively. Each image set was georeferenced to the UTM coordinate system in order to allow us to study the river channel evolution. The starting and ending coordinates were determined along the river itself. To obtain the portion of the river as the study area, we relied on satellite imagery. Specifically, the river path from the satellite imagery was extracted by performing reclassification using a combination of the ISO Cluster and Maximum Likelihood Classification algorithms from Arc GIS 9.2. At the end of this process, we were able to know the meandering of the river for each year for all four Landsat image sets. A centerline was then created on the obtained river path by collapsing the dual lines to centerline. This was done using the generalization tool in Droppova (2011) that basically determines the centerline from double-line features (Droppova, 2011). The output of the collapsed dual lines includes a field that saves three-line type values; ' 1 ' for obtained centerline, ' 2 ' for a line around unsolved junctions exceeding the specified limit of width, and ' 3 ' for joining lines within junctions (Lee and Hardy, 2006).

Points were then generated along the line in order to divide the whole length of the river into $5 \mathrm{~km}$ segments; with the last segment being lesser in length. Orthogonal lines were drawn on the centerline on the river for all the segments and the length of each segment was measured. Next, each segment was characterized using a sinuosity index (SI). This value is not fixed and affects the SI value, so the smaller the value, the more accurate the calculation of SI. The previous study (Shakti et al. 2011) uses $10 \mathrm{~km}$ for each segment. Therefore, using smaller segments in this case (i.e. $5 \mathrm{~km}$ ) should give results that are more accurate.

SI can be calculated based on Equation 1.

$$
\mathrm{SI}=\frac{L_{\max }}{L_{r}}
$$


where $S I$ is the Sinuosity Index, $L_{\max }$ the length along the channel and $L_{r}$ the length of the meander belt. Intuitively, SI is the ratio of the measured distance between two stations on the river stream to the shortest horizontal distance between the two stations (Panda and Bandyopadhyay. 2011). SI basically determines the river channel characteristics and has been applied in works such as Mueller (1968); Ahmed and Fawzi (2011) and Kumar et al. (2016).

In this work, $S I<1.05$ is classified as straight, $S I=$ $[1.05,1.50)]$ means the segment is sinuous and, $S I>1.5$ means the river segment is meandering. The variation from the common manner occurs due to the down-valley track is not absolutely straight. So, the sinuosity index can be described as the aberrations from a track specified by the course of the maximum downslope. For that, the streams that move direct downslope have a $\mathrm{SI}=1$, and meandering rivers have an $\mathrm{SI}>1$ (Mueller, 1968).

\section{RESULTS}

The satellite imageries indicate the Zab River path had migrated in the years 1989, 1999, 2015 and 2019. Table 1 shows the Landsat image categories used in this study. The corresponding evolution of the river channel is shown in Table 2 where the SI from each satellite imagery set is calculated.

\begin{tabular}{|l|c|c|c|c|}
\hline $\begin{array}{l}\text { Satellite } \\
\text { images }\end{array}$ & $\begin{array}{l}\text { Date } \\
\text { acquired }\end{array}$ & $\begin{array}{l}\text { Band } \\
\text { Resoluti } \\
\text { on }(\mathrm{m})\end{array}$ & Path/Row & $\begin{array}{l}\text { Cloud } \\
\text { cover } \\
(\%)\end{array}$ \\
\hline $\begin{array}{l}\text { Landsat-5 } \\
\text { TM }\end{array}$ & $1989 / 7 / 7$ & $30 \mathrm{~m}$ & $169 / 036$ & 0 \\
$\begin{array}{l}\text { Landsat-7 } \\
\text { ETM+ }\end{array}$ & $1999 / 11 / 8$ & $30 \mathrm{~m}$ & $169 / 036$ & 0 \\
Landsat-8 & $2015 / 7 / 7$ & $30 \mathrm{~m}$ & $169 / 036$ & 0 \\
Landsat-8 & $2019 / 7 / 2$ & $30 \mathrm{~m}$ & $169 / 036$ & 0 \\
\hline
\end{tabular}

Table 1. Landsat image categories used in the study.

Upon further observation of all SI values, the classifications for most of the segments show ranges indicating rivers being sinuous and meandering. Segment N1 was the only exception by classified as a straight $(S I=0.2)$; this is actually the end of the river in 2015 . We postulate that $\mathrm{N} 1$ is straight since the segment is only $\sim 300 \mathrm{~m}$ from where the river terminates. Therefore, it would have little chance of reshaping to either a sinusoidal or a meandering shape. This is clearly illustrated in Figure 2(c).

As shown in Fig. 2(a) - 2(d) shows the active segments streams for the years 1989, 1999, 2015, and 2019. From Table 2, segments A, B, C, H, J, K, L, and M have a calculated $S I \geq 1.5$ in 1989, which indicates meandering along the river paths. In 1999, segments A, B, C, D, G, H, L, M, and N reported SI $\geq 1.5$, which again shows meandering and also, judging for the image, continued meandering in various parts of the river. Similarly, the SI at segments A, B, C, F, K, L, and M were also meandering one in the years 2015 and 2019. Meandering continued in the same segments for two years.

The river's path is sinuous at some segments and more meandered in others. The field measurement of changed positions was found to matched with the obtained result. The extreme shift was in the eastern part of the study area along the Zab River (i.e. segments C and D) where the river passes near Kirkuk city. It is also noted that a high shift of the river path in segments E, G, and F passes through the Arbil city and K segment near Sulaymaniyah city.

All the annual changes can be visualized in the composite image Figure 2e. This shows the shift in the position of Zab River throughout the years 1989, 1999, 2015, and 2019.

The total length in each year's satellite image has been calculated and compared in order to show the yearly shift and changes. From the length calculations, reshaping occurred mostly from 1989 to 1999 where a $2.155 \mathrm{~km}$ increase in length was reported. Decreases however followed from 1999 to 2015 by $1.856 \mathrm{~km}$, which continued until 2019 by $0.236 \mathrm{~km}$. Table 3 shows the overall length variations.

\begin{tabular}{|l|l|l|l|l|}
\hline Year & $\begin{array}{l}\text { Length } \\
(\mathrm{km})\end{array}$ & $\begin{array}{l}\text { River } \\
(\text { all } \\
\text { years })\end{array}$ & X & Y \\
\hline 2019 & 65.062 & Start & 422383.89 & 3957753.38 \\
2015 & 65.299 & & 461447.64 & 3969366.9 \\
1999 & 67.155 & End & & \\
1989 & 65 & & & \\
\hline
\end{tabular}

Table 3. The overall variation of river length by year.

\begin{tabular}{|c|c|c|c|c|c|c|c|c|c|}
\hline Segment & $\begin{array}{c}L_{\max } \\
(\mathrm{km})\end{array}$ & $\begin{array}{c}L_{r}(\mathrm{~km}) \\
\mathbf{1 9 8 9}\end{array}$ & $\begin{array}{c}\mathrm{Lr}(\mathrm{km}) \\
\mathbf{1 9 9 9}\end{array}$ & $\begin{array}{c}L_{r}(\mathrm{~km}) \\
\mathbf{2 0 1 5}\end{array}$ & $\begin{array}{c}L_{r}(\mathrm{~km}) \\
\mathbf{2 0 1 9}\end{array}$ & $\begin{array}{c}\text { SI } \\
\mathbf{1 9 8 9}\end{array}$ & $\begin{array}{c}\text { SI } \\
\mathbf{1 9 9 9}\end{array}$ & $\begin{array}{c}\text { SI } \\
\mathbf{2 0 1 5}\end{array}$ & $\begin{array}{c}\text { SI } \\
\mathbf{2 0 1 9}\end{array}$ \\
\hline $\mathbf{A}$ & 5.00 & 3.00 & 2.99 & 2.98 & 2.98 & 1.67 & 1.67 & 1.68 & 1.68 \\
$\mathbf{B}$ & 5.00 & 1.73 & 1.83 & 1.80 & 1.80 & 2.88 & 2.73 & 2.78 & 2.78 \\
$\mathbf{C}$ & 5.00 & 1.97 & 1.85 & 2.90 & 2.85 & 2.54 & 2.70 & 1.73 & 1.75 \\
$\mathbf{D}$ & 5.00 & 3.67 & 3.18 & 3.38 & 3.52 & 1.36 & 1.57 & 1.48 & 1.42 \\
$\mathbf{E}$ & 5.00 & 3.69 & 3.49 & 3.87 & 3.52 & 1.35 & 1.43 & 1.29 & 1.42 \\
$\mathbf{F}$ & 5.00 & 3.52 & 4.11 & 2.74 & 2.50 & 1.42 & 1.22 & 1.83 & 2.00 \\
$\mathbf{G}$ & 5.00 & 4.14 & 2.95 & 3.50 & 3.99 & 1.21 & 1.70 & 1.43 & 1.25 \\
$\mathbf{H}$ & 5.00 & 3.31 & 2.38 & 3.51 & 3.42 & 1.51 & 2.10 & 1.42 & 1.46 \\
$\mathbf{I}$ & 5.00 & 3.86 & 3.91 & 3.59 & 3.97 & 1.30 & 1.28 & 1.39 & 1.26 \\
$\mathbf{J}$ & 5.00 & 3.25 & 3.56 & 3.55 & 3.62 & 1.54 & 1.40 & 1.41 & 1.38 \\
$\mathbf{K}$ & 5.00 & 2.99 & 3.46 & 3.10 & 2.96 & 1.67 & 1.44 & 1.61 & 1.69 \\
$\mathbf{L}$ & 5.00 & 1.35 & 3.17 & 1.66 & 1.41 & 3.69 & 1.58 & 3.01 & 3.55 \\
$\mathbf{M}$ & 5.00 & 2.64 & 0.93 & 2.34 & 2.60 & 1.90 & 5.37 & 2.14 & 1.93 \\
$\mathbf{N}$ & 2.16 & - & 1.22 & - & - & - & 1.76 & - & - \\
$\mathbf{N 1}$ & 0.30 & - & - & 1.51 & - & - & - & 0.20 & - \\
N2 & 0.06 & & & & 0.03 & - & - & - & 2 \\
\hline
\end{tabular}

Table 2. Sinuosity Indices of the Zab River segments from different years of satellite imagery. 

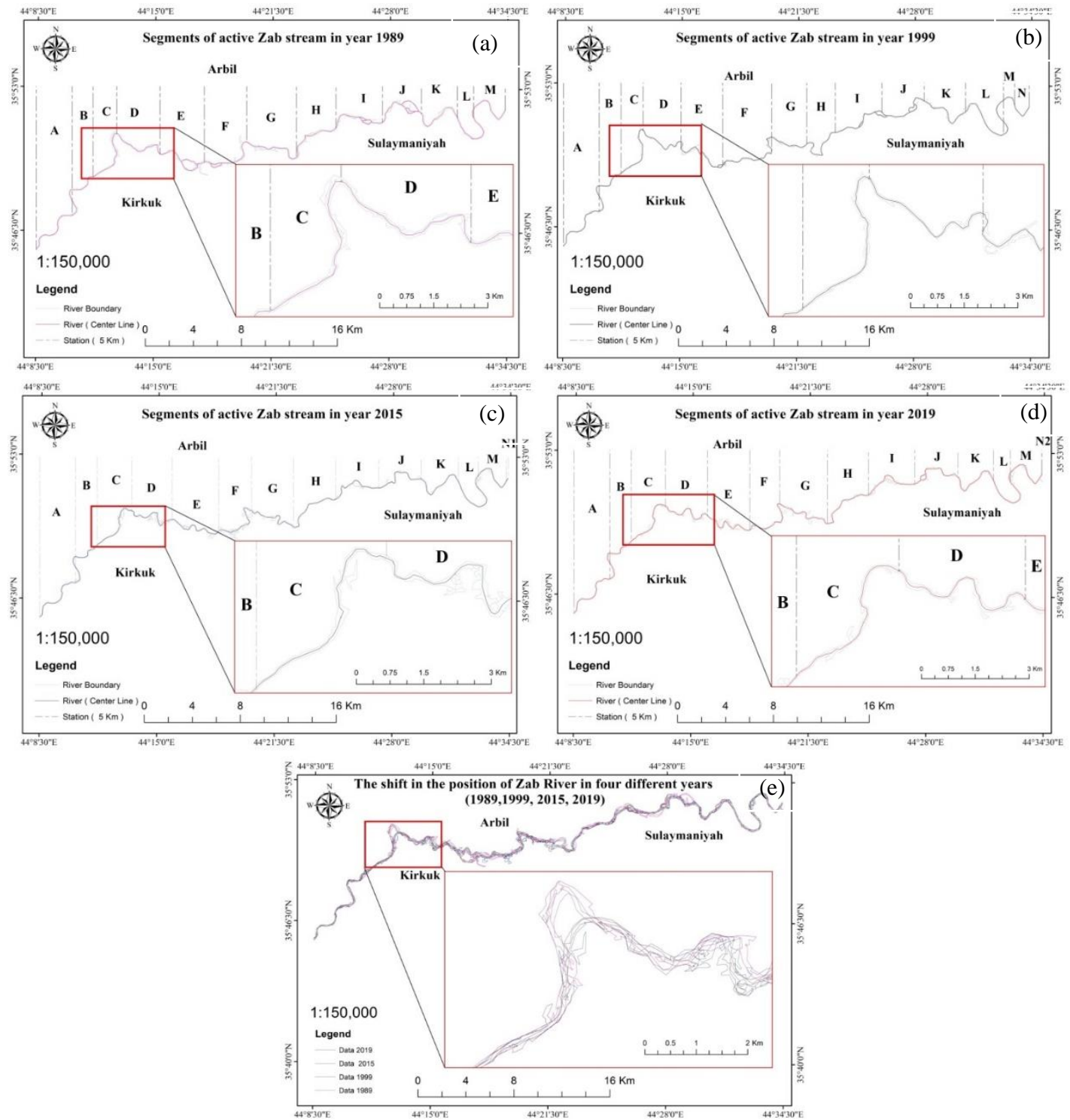

Figure 2. Segments of active Zab stream in years a)1989, b)1999, c) 2015, d) 2019, e) the shift in the position of Zab River in four different years $(1989,1999,2015,2019)$.

\section{CONCLUSION}

Identifying fluvial landforms is important in the study of riverbank changes. Satellite remote sensing technology and GIS are helpful tools to distinguish fluvial landforms and mapping the related land changes over a specific time. This study used the Sinuosity Index and remote sensing analysis integrated with Geographic Information Systems (GIS) in order to determine the meandering and sinuosity of the Zab River in Iraq. The study utilized four sets of satellite data for the years 1989, 1999, 2015 and 2019. The analysis of this study using Landsat imagery and GIS shows the migration of the Zab River course over space and time. The study concluded that the SI of the Zab River ranges from 1.21 to 5.37 between meandering and sinuous behavior. The extreme meandering was shown in the eastern part of the study area along the river, in the sections close to Kirkuk.

\section{REFERENCES}

Aher, S.P., Bairagi, S.I., Deshmukh, P.P. and Gaikwad, R.D., 2012. River change detection and bank erosion identification using topographical and remote sensing data. Int J Appl Inf Syst, 2, pp.1-7.
Ahmed, A.A. and Fawzi, A., 2011. Meandering and bank erosion of the River Nile and its environmental impact on the area between Sohag and El-Minia, Egypt. Arabian Journal of Geosciences, 4(1-2), pp.1-11.

Al-Saady, Y., Merkel, B., Al-Tawash, B. and Al-Suhail, Q., 2015. Land use and land cover (LULC) mapping and change detection in the Little Zab River Basin (LZRB), Kurdistan Region, NE Iraq and NW Iran.FOG-Freiberg Online Geoscience, 43.

Al-Saady, Y.I., Al-Suhail, Q.A., Al-Tawash, B.S. and Othman, A.A., 2016. Drainage network extraction and morphometric analysis using remote sensing and GIS mapping techniques (Lesser Zab River Basin, Iraq and Iran). Environmental Earth Sciences, 75(18), p.1243. doi: 10.1007/s12665-016-6038-y

Brice, J.C., 1964. Channel patterns and terraces of the Loup Rivers in Nebraska. US Government Printing Office. 
Callander, R.A., 1978. River meandering. Annual Review of Fluid Mechanics, 10(1), pp.129-158.

Das, P., 2012. Study of Barak River meander and associated hazard around Silchar town, Assam, using remote sensing and GIS. Earth Science India.

Droppova, V., 2011. The tools of automated generalization and building generalization in an ArcGIS environment. Slovak Journal of Civil Engineering,19(1), pp.1-7. DOI: 10.2478/v10189-011-0001-4

Hecher, J., Filippi, A., Guneralp, I. and Paulus, G., 2013. Extracting river features from remotely sensed data: An evaluation of thematic correctness.

Hooke, J.M., 1984. Changes in river meanders: a review of techniques and results of analyses. Progress in Physical Geography, 8(4), pp.473-508.

Jumaah, H.J., Ameen, M.H., Kalantar, B., Rizeei, H.M. and Jumaah, S.J., 2019. Air quality index prediction using IDW geostatistical technique and OLS-based GIS technique in Kuala Lumpur, Malaysia. Geomatics, Natural Hazards and Risk, 10(1),pp.2185-2199.

https://doi.org/10.1080/19475705.2019.1683084

Jumaah, H.J., Mansor, S., Pradhan, B. and Adam, S.N., 2018. UAV-Based PM2. 5 Monitoring for Small-Scale Urban Areas. International Journal of Geoinformatics, 14(4). https://www.researchgate.net/publication/333378629_UAVbase d_PM25_monitoring_for small-scale_urban_areas

Kamarudin, M.K.A., Toriman, M.E., Rosli, M.H., Juahir, H., Aziz, N.A.A., Azid, A., Zainuddin, S.F.M. and Sulaiman, W.N.A., 2015. Analysis of meander evolution studies on effect from land use and climate change at the upstream reach of the Pahang River, Malaysia. Mitigation and Adaptation Strategies for Global Change, 20(8), pp.1319-1334.

Kotoky, P., Bezbaruah, D., Baruah, J. and Sarma, J.N., 2005. Nature of bank erosion along the Brahmaputra river channel, Assam, India. Current science, pp.634-640.

Kumar, B.A., Gopinath, G. and Chandran, M.S., 2014. River sinuosity in a humid tropical river basin, south west coast of India. Arabian Journal of Geosciences, 7(5), pp.1763-1772.

Kumar, D., Singh, D.S., Prajapati, S.K., Khan, I., Gautam, P.K. and Vishawakarma, B., 2018. Morphometric parameters and neotectonics of Kalyani river basin, Ganga plain: A remote sensing and GIS approach. Journal of the Geological Society of India, 91(6), pp.679-686.

Kumar, M., Denis, D.M. and Gourav, P., 2016. Study of meandering of river Ganga near Allahabad (India), using remote sensing and GIS techniques. Asian Journal of Environmental Science, 11(1), pp.59-63. DOI: 10.15740/HAS/AJES/11.1/59-63

Kusratmoko, E., Wibowo, A. and Kurnia, A.A., 2019, November. Changes in the Value of Sinuosity Index in Komering River Channel, Province South Sumatera Years 1990-2016. In IOP Conference Series: Earth and Environmental Science (Vol. 338, No. 1, p. 012024). IOP Publishing. doi:10.1088/1755-1315/338/1/012024
Lee, D. and Hardy, P., 2006. Design and experience of generalization tools. In Proceedings of AutoCarto. https://www.researchgate.net/publication/228950686

Leopold, L.B. and Wolman, M.G., 1957. River channel patterns: braided, meandering, and straight. US Government Printing Office.

Mojaddadi, H., Pradhan, B., Nampak, H., Ahmad, N. and Ghazali, A.H.B., 2017. Ensemble machine-learning-based geospatial approach for flood risk assessment using multi-sensor remote-sensing data and GIS. Geomatics, Natural Hazards and Risk, 8(2), pp.1080-1102.

Mueller, J.E., 1968. An introduction to the hydraulic and topographic sinuosity indexes. Annals of the Association of American Geographers, 58(2), pp.371-385. https://doi.org/10.1111/j.1467-8306.1968.tb00650.x

Panda, S. and Bandyopadhyay, J., 2011. Morphodynamic changes of Bhagirathi river at Murshidabad district using geoinformatics. Journal of Geographic Information System, 3(01), p.85.

Parker, G., 1976. On the cause and characteristic scales of meandering and braiding in rivers. Journal of fluid mechanics, 76(3), pp.457-480.

Saeedrashed, Y. and Guven, A., 2013. Estimation of geomorphological parameters of Lower Zab River-Basin by using GIS-based remotely sensed image. Water resources management, 27(1), pp.209-219. DOI 10.1007/s11269-0120179-x

Sapkale, J.B., Kadam, Y.U., Jadhav, I.A. and Kamble, S.S., 2016. River in Planform and Variation in Sinuosity Index: A Study of Dhamni River, Kolhapur (Maharashtra), India. Int. J. Sci. Eng. Res, 7, pp.863-867.

Suryavanshi, S., Denis, D.M., Kumar, D. and Tirkey, G., 2011. Stream dynamics change analysis of River Chambal using Remote Sensing and GIS techniques. International Journal of Geomatics and Geosciences, 1(4), pp.813-820.

Shields Jr, F.D., Simon, A. and Steffen, L.J., 2000. Reservoir effects on downstream river channel migration. Environmental Conservation, 27(1), pp.54-66.

Surian, N., 1999. Channel changes due to river regulation: the case of the Piave River, Italy. Earth Surface Processes and Landforms: The Journal of the British Geomorphological Research Group, 24(12), pp.1135-1151.

Suryavanshi, S., Denis, D.M., Kumar, D. and Tirkey, G., 2011. Stream dynamics change analysis of River Chambal using Remote Sensing and GIS techniques. International Journal of Geomatics and Geosciences, 1(4), pp.813-820.

Thompson, A., 1986. Secondary flows and the pool-riffle unit: A case study of the processes of meander development. Earth Surface Processes and Landforms, 11(6), pp.631-641. 